\title{
A METHODOLOGY FOR EXAMINING GEOTOURISM POTENTIAL AT THE KRUGER NATIONAL PARK, SOUTH AFRICA
}

\author{
Khodani MATSHUSA* \\ College of Business and Economics, School of Tourism and Hospitality, \\ University of Johannesburg, South Africa, PO Box 524, Auckland Park, 2006, South Africa, e-mail: matshusakhodani@yahoo.com
}

Peta THOMAS

College of Business and Economics, Department of Business Management, University of Johannesburg, South Africa, PO Box 524, Auckland Park, 2006, South Africa, e-mail: pthomas@uj.ac.za

\section{Llewellyn LEONARD}

School of Ecological and Human Sustainability, Department of Environmental Sciences,

University of South Africa, South Africa, PO Box 392, UNISA, South Africa, e-mail: 1lewel@unisa.ac.za

Citation: Matshusa, K., Thomas, P., \& Leonard, L. (2021). A METHODOLOGY FOR EXAMINING GEOTOURISM POTENTIAL AT THE KRUGER NATIONAL PARK, SOUTH AFRICA. GeoJournal of Tourism and Geosites, 34(1), 209-217. https://doi.org/10.30892/gtg.34128-639

\begin{abstract}
In contrast to Europe, Asia and South America where geotourism is actively pursued, geotourism activities in South Africa have not to-date been a focus of tourism products. The purpose of this paper is to propose a field methodology that can be used to assess the potential for geotourism development. Existing procedures to establish geotourism site potential are reviewed and a new methodology that accounts for more characteristics than currently found in documented methods is proposed. This consists of three phases: creating a standardised manner of inventorying the sites; standardising field rank scoring for each site by geotourism value, cultural value, ecological sensitivity, accessibility, de velopment requirements, currently available academic literature, and, developing a final multi-site database assisting the South African National Parks to preserve geoheritage sites. Based on previous studies, the Kruger National Park has geoheritage sites that could form the basis for geotourism development: therefore, the methodology was piloted in its northern regions at well-known geoheritage sites. The findings of this study intend to assist the South African National Parks, local community leaders, the private sector (including existing tour operators) and government departments in achieving a national database of geoheritage sites to ultimately be associated with sustainable tourism activity led by local communities.
\end{abstract}

Key words: geotourism, sustainability, geoheritage, Kruger National Park, South Africa

\section{INTRODUCTION}

Geotourism, is a form of tourism which sustains and enhances the identity of a territory, by taking into consideration the territory's geology, environment, culture, aesthetics, heritage, and, the wellbeing of its residents (International Congress of Geotourism, 2011). Worldwide, geotourism is gaining popularity (Ren et al., 2013) being used as a vehicle to foster sustainable tourism development through establishing local guardian communities who benefit from associated geotourism activity. The objective of this paper is to propose a methodology for documenting and ranking South African geoheritage sites, in the Kruger National Park (KNP). The methodology finally used to select the KNP localities that could be geoheritage sites contributes to creating a KNP database of geoheritage sites.

An increased interest in geological and heritage awareness has stimulated interest in geotourism as a tourism product particularly as it often shares management responsibility with local communities and national guardians. This has precipitated a phenomenal rise in dedicated geoparks and geotourism activities with this interest further used as a tool for geoheritage conservation (Newsome and Dowling, 2010). South Africa has yet to establish a field ranking methodology that collects data by standardised geotourism characteristics to assess what sites to develop. The KNP is the largest South African public park within the South African National Parks (SANParks) with an established tourism clientele focused on wildlife viewing (Schutte, 2003; Scholtz et al., 2013; Grünewald et al., 2016). Previous studies (StricklandMunro et al., 2010; Strickland-Munro and Moore, 2014) highlight that the KNP needs to create more job opportunities to reduce poverty within nearby local communities. Neglecting geotourism potentially misses an opportunity for sustainable geotourism activity development by local communities. This study focused on the northern part of the KNP located in Limpopo Province and was selected because of its uniqueness due to its diverse assemblage of rock formations (South African National Parks, 2017), significant cultural and archaeological ruins like Thulamela and Makahane heritage sites. In addition, communities bordering the northern part of the KNP are poorer and benefit less from tourism activities than those communities abutting the southern part of the park as fewer tourists visit the north (Matiza and Oni, 2014). This study develops a methodology that will provide the opportunity to develop a database of geoheritage sites assessable by their collected characteristics as to their potential for geotourism development to create local jobs. This research contributes to opening up new rural community economic opportunities in accordance with recommendations by Farsani et al. (2011) and Ehsan et al. (2016).

These studies all concur that geotourism is a branch of sustainable tourism that can be used for poverty alleviation, geo-conservation, and the development of rural economies. Furthermore, this study can also help to identify the KNP in tourism literature not only famed for its wildlife but also as a geopark. The United Nations Educational Scientific and Cultural Organization (UNESCO) Global Geoparks (UGGp) (Zouros, 2016) engages in defining a globally recognised significant geopark territory (Justice, 2018: 2) as a "single, unified geographical areas where sites and landscapes of international geological significance are managed with a holistic concept of protection, education, and sustainable development" (United Nations Educational, Scientific and Cultural Organization, 2018a). The next sections provide literature that underpins the rationale for the development of a South African geotourism assessment instrument and discusses the concept of geotourism, global overview of geotourism, geotourism in South Africa, tourist motivation towards geotourism and benefits of geotourism.

\footnotetext{
* Corresponding author
} 


\section{LITERATURE REVIEW}

Definitions of geotourism have evolved as tourist needs began to focus on geological heritage and geoconservation, incorporating notions such as understanding others' cultures, personal education and, sustainability in terms of the importance of recognis ing the need to preserve these sites and indigenous communities who cohabit with or near them (Newsome et al., 2012; Hose, 2016). The scientific literature reveals a multitude of concepts and definitions concerning geotourism (Wimbledon, 2013; Ruban, 2015; Boley et al., 2011; Gordon, 2018) often using terminologies such as geodiversity, geoconservation, geoheritage, and geosite in different ways (Brilha, 2016; Brilha, 2018). A succinct and clear description of geoheritage and its relationship to geotourism by Newsome a nd Dowling (2018: 305) state, "geoheritage refers to the elements of the earth that we value, whereas geotourism is a type of tourism that is based on some aspects of the earth's geological and/or geomorphological heritage" but what the concepts of geotourism and geoheritage encompass is widely argued in literature. Dowling and Newsome (2010) suggest that geotourism is two parts thus, geo and tourism: 'geo' means geology and geomorphology while 'tourism' refers to visiting learning, appreciating and engaging with geosites. However, this suggestion and the former lack the emphasis on the wellbeing of residents or historic guardians as inferred in the UGGp UNESCO definition. Ehsan et al. (2013: 1713) capture this omission defining geotourism as a "tool for sustainable development of geoheritage resources". This definition is considered by many authors as too broad and susceptible to misinterpretation as there are so many differing opinions about the concept of what sustainable development is (Munasinghe, 1993; Goodland, 1995; Mitcham, 1995; Harris, 2000; Nooten, 2007; Emas, 2015). Establishing a definition that guides the development of a South African site assessment instrument that encompasses characteristics that help determine where sites can realistically be developed for local community guardians hip and benefit, becomes critical. Hose (2012: 4) further claims that no studies have adequately covered the "current breadth of modern geotourism in terms of the nature of provision and geographical coverage, together with its theoretical underpinnings" which this study tries to address. For this paper, geotourism is considered in terms of 'cultural heritage' as defined in Article one of the 1972 UNESCO Convention (United Nations Educational, Scientific and Cultural Organization, 1972a: 80):

"Monuments: architectural works, works of monumental sculpture and painting, elements of structures of an archeological nature, inscriptions, cave dwellings and combinations of features, which are of outstanding universal value from history, art or science;

Groups of buildings: groups of separate or connected buildings, which, because of their architecture, their homogeneity or their place in the landscape, are of outstanding universal value from history, art or science;

Sites: works of man or the combined works of nature and man, and areas including archeological sites which are of outstanding universal value from the historical, aesthetic, ethnological or anthropological points of view".

It is necessary if using the 1972 UNESCO convention definition to develop a methodology for determining the potential for developing a geotourism product that can incorporate all the UNESCO criteria. Worldwide research reveals that tourists seek authentic travel experiences (Reimold, 2001; Stokes et al., 2003; Phau et al., 2013; Chingombe and Taru, 2018) such as geotourism.

As regards what is considered geoheritage Lima et al. (2010: 1) note, "the UNESCO's Convention concerning the protection of the world cultural and natural heritage, signed in Paris in 1972, was the first international effort to select sites of paramount world importance due to their natural characteristics". The protection of geosites as such a high priority that they it has been proposed that geological heritage and geodiversity must be taken into consideration when designing International Union of Conservation of Nature (IUCN) programmes (Carcavilla et al., 2009). Carcavilla et al. (2009) note that globally, a minority of countries do see geoconservation as an essential activity and currently, three international programs working with IUCN programmes are creating opportunities to protect geological (geo) heritage as follows: the UNESCO World Heritage Convention; the Biosphere Reserves; and, Wetlands of International Importance (Ramsar Agreement). In connection with protecting geological heritage, three more categories are distinguished by Dingwall (2005):

- Human heritage locations with geological aspects as their main feature;

- Places of value for other non-geological reasons;

- Areas with minor or indirect geological value.

Newsome et al. (2012: 20) note that, "in recent years there has [however] been a rapid expansion of tourism interest in geological features and landscapes, both within existing protected areas due to the recognition and identification of geosites via geo-conservation activities, governmental recognition of geo-heritage and the emergence of a complex tourism demographic that is more demanding of new, unique and educative experiences". In addition, in Europe there is a rapidly expanding geopark movement, as well as the establishment of a number of organisations that actively promote geotourism and the conservation of geodiversity.

Ruban (2015) summarised the number of journal articles published globally on geotourism between $2012-2014$ and found that there was limited research conducted on the subject. From the article summary it was found that there are 179 published articles on geotourism in Europe, 104 on Asia and 29 on Africa. Only approximately 10 of the publications on Africa dealt with South African geoheritage. It is clear that there is paucity of information in South Africa in terms of realising the potential from geotourism by undertaking empirical research to guide its development. Geotourism can assist to create local enterprises, new jobs (Dowling and Newsome, 2010) and educate tourists and local people on the need to protect geopark attributes (Zouros, 2016). For example, geotourism has been effectively utilised to link geology and culture, establish local enterprises, educate tourists and local people in order to promote conservation of geoheritage sites in Europe, Asia, Australia and Canada (Newsome et al., 2012; Badang and Unjah, 2013; Iftode and Niculae, 2016; Arora et al., 2020; Paungya et al., 2020; Rozenkiewicz et al., 2020; Santangelo and Valente, 2020; Widawski et al., 2020). Geotourism offers opportunities to conserve natural heritage sites whilst enhancing the socio-economic status of the local communities. In addition, Ehsan et al. (2013: 1711) show that geotourism offers a "realistic key solution to the apparent conflict between environmental and cultural protection and economic growth". Half of all travellers are reported as supporting controlled access to historic sites so that they may be preserved and protected (Stokes et al., 2003).

Geotourism provides greater potential for the development of aligned educational facilities used to educate tourists and local people. Geotourism assisted in the creation of innovative local enterprises, new jobs, and high quality guide training courses as new sources of revenue, while the geological resources of the area are protected (Dowling and Newsome, 2010; United Nations Educational, Scientific and Cultural Organization, 2016). Other researchers (Härtling and Meier, 2010; Jeon et al., 2016) indicate good economic results for local communities from implementing geotourism as a secondary tourism offering to supplement existing wildlife tourism in parks. However, in the world as a whole, many countries make no official recognition that geosites are cultural and scientific places of national importance (Wimbledon, 2013). UNESCO's UGGp programme has identified over 100 geoparks in 29 countries (United Nations Educational, Scientific and Cultural Organization, 2016). However, as at 2019 only one UNESCO geopark is currently recognised in Africa (Ngorongoro Lengai UNESCO Global Geopark in Tanzania) and none in South Africa (United Nations Educational, Scientific and Cultural Organization, 2018b).

Geotourism undertakings in South Africa are governed by regulations in the National Heritage Resources Act, Act No. 25 of 1999. Geotourism in South Africa has yet to be developed by the National Tourism Department. Reasons for this include lack of institutional 
and public participation in geology (Reimold, 1999), lack of data on important geological or geomorphological sites, conflation of geological with other ecological and cultural heritage issues (Reimold, 1999) and, problems with creating relevant legislation for effective management (Cairncross, 2011). Limited studies by various authors have been conducted on geoheritage sites specific to South African geological and mining heritage (Viljoen and Reimold, 1999; Reimold, 2001; Smit, 2003; Gibson and Blom, 2008; Schutte, 2009; Knight et al., 2015; Anhaeusser et al., 2016; Taru and Chingombe, 2016; Mukwada and Sekhele, 2017). Schutte (2003) notes that South Africa has many natural resources often of a geoheritage nature, not utilised for educational, recreational, or tourism purposes. Saayman (2017) considers the potential of tourists to explore South Africa from aspects other than wildlife as having great potential while Ginting and Febriand (2018: 2) see "geotourism bringing benefits to the tourist and local people" where tourists get a unique travel experience and local people get economic benefits from tourist visits (Boley et al., 2011).

According to Gibson and Blom (2008) development and effective management of geological and other heritage resources as tourism and educational resources has the potential to uplift an economically depressed region and act as a flag-bearer for the development of other geological heritage resources in South Africa. However, previous research indicates that few communities abutting the park are benefiting from the current form of tourism (wildlife) at the KNP. For example, in 2012 SANParks reported only three abutting communities (Makuleke, Nkambeni and Mjejane) benefited from contractual financial generating agreements with the KNP (South African National Parks, 2012). Previous studies (Strickland-Munro et al., 2010; Strickland-Munro and Moore, 2014) highlight that the KNP has not done enough to create jobs and reduce poverty within the nearby local communities. According to El Wartiti et al. (2009: 143) "geological heritage sites, properly managed, can generate employment and new economic activities, especially in rural regions in need of new or additional sources of income". However, at the time of this research there were no published plans for geotourism development at the KNP, yet geotourism can offer a new secondary product to supplement the existing tourism thereby positively utilising natural resources for the benefits of the local people. It is therefore important for the KNP to consider seriously market diversification and venture into ge otourism as a secondary market that will contribute towards sustainable tourism. This will not only create jobs and help alleviate poverty, but will strategically position the KNP for future tourism market demand. This research was also aligned with the United Nations (UN), African Union (AU) and South African goals towards sustainable development. According to the UN, poverty alleviation and job creation remains the centre of the Millennium Development Goals: Lack of job opportunities is one of the major contributing factors to poverty in South Africa. As a result, the report by the United Nations Economic Commission for Africa (UNECA) indicated that South Africa has listed fighting poverty alleviation and job creation as one of its su-regional sustainable development priorities (United Nations Economic Commission for Africa, 2015). The findings by Mukwada and Sekhele (2017) suggest the need to address a conundrum of intertwined endogenous and exogenous conditions as a strategy for enhancing the viability of community-based geotourism projects. Knight et al. (2015) documented the examples of geoheritage sites in South Africa such as the West Coast Fossil Park and Makapan Valley Heritage Site.

South Africa holds 10 of the UNESCO's world heritage sites: Fossil Hominid Sites of South Africa also known as the Cradle of Humankind (cultural and anthropological interest), Mapungubwe (cultural landscape site), Richtersveld Cultural and Botanical Landscape (cultural and botanical heritage interest), Khomani Cultural Landscape (cultural heritage interest), Robben Island (cultural heritage interest), Cape Floral Region Protected Areas (plant biodiversity interest), Barberton Makhonjwa Mountains, (geological interest), Maloti-Drakensberg Park (geological and biological diversity interest), iSimanaliso Wetland Park (geological and biodiversity interest) and Vredefort Dome (geological interest). Nevertheless, Reimold (2001) and Schutte (2003) note that these natural resources are not utilised enough, either for educational, recreational, or tourism purposes. Reimold (2001: 22) also noted that "several hundred important natural sites are not properly accounted or inventoried, nor are they protected". Moreover, while structures exist in South Africa to pursue and implement protection of geological sites, lack of manpower and funding do present persistent problems to geotourism development (Reimold, 1999; Smit, 2003). The potential contribution to local sustainable development from use of these national geoheritage sites is not being realised. Development of an instrument to value geotourism opportunities within the K NP hopes to provide opportunity to develop new geotourism products that are run by and employ rural communities near the KNP.

\section{METHODOLOGY}

This research involved developing a field instrument to aid national parks in South Africa and particularly the KNP in the creation of an inventory of geoheritage sites. This research focused specifically on establishing and field-testing a geoheritage field survey instrument developed and extending past researchers work on geoheritage forms (see phase 1). The field-testing of the form focused on the northern region of the KNP where community involvement in tourism activities is to-date very limited. The lack of jobs created in the north is largely because the northern regions of the park are a considerable distance to travel to by road and the north has no commuter airfield. In contrast, the southern end of the park utilises community members to a far greater extent as the tourism visitors are very large every year, which encourages job creation employing people from abutting rural communities. The southern end of the park is only 5 hours' drive from South Africa's international airport and port of entry, Oliver Tambo International Airport. The KNP also has its own internal park airfield that runs several daily commuter flights from Oliver Tambo International Airport into Skukuza situated in the south and the airfield is ten minutes' drive from the largest KNP accommodation camp.

The southern end of the park has similar wildlife offerings to the north so tourists do not generally drive from the southern to the northern end as it takes 5 days by road. Consequently, the north is not as developed as regards creating jobs through accommodation and other services. The South African National Parks have not todate focused on developing tours related to geoheritage sites as a way to create jobs nationally and this research sought to help establish a field survey instrument that would fit the peculiar circumstances of South African parks. These circumstances include the fact that tours to geoheritage sites will need a road infrastructure to reach sites and generally, tourists will need to be accompanied by a trained field guide/tour guide to be able to walk in safety to a site due to a prevalence of wild, dangerous animals. This study adopted a three phase methodological approach as shown in Figure 1.

Phase 1

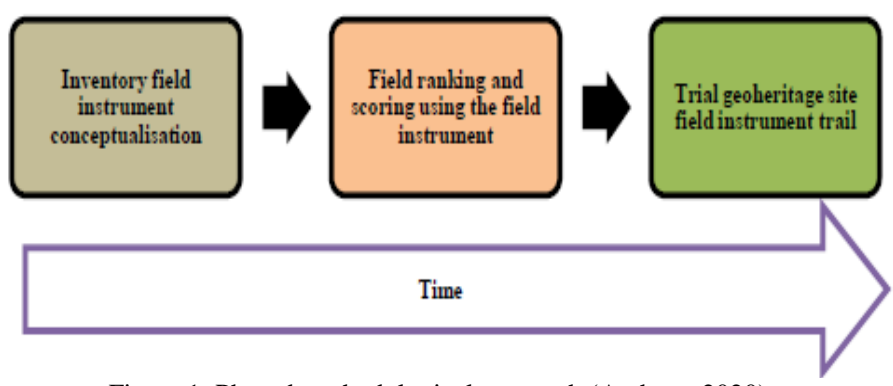

Figure 1. Phased methodological approach (Authors, 2020)

This study was conducted with the permission of SANParks who considered the results vital in the identification of geoheritage sites in a manner specific to the recognition of the wildlife and vegetation, national park biomes and, South African legislation in considering 
strategy for the development of geotourism at the northern part of the KNP. Consequently, the results of this study are vital in developing geotourism at the northern part of the KNP.

\section{PHASE ONE: INVENTORY FIELD INSTRUMENT CONCEPTUALISATION}

"The development of a geosites' inventory should be the first step in any geoconservation strategy" (Lima et al., 2010: 1). This methodology to create an inventory began first by identifying a methodology to standardise categories for noting geosite characteri stics with special emphasis on using the instrument in the context of a national park. This was done by reviewing previous related methodological studies for assessing geoheritage site potential. This included critiquing the field methodologies recommended to-date summarised in Table 1 with critiques of why each would not have been suitable for a national park.

Table 1. Critique of existing geoheritage survey forms (Authors, 2020)

\begin{tabular}{|c|c|c|}
\hline Author/s & Limitations of the instrument & New approach adopted by this study \\
\hline Brilha (2016) & $\begin{array}{l}\text { - The methodology proposed by Brilha }(2016,2018) \text { does not } \\
\text { include cultural value as one of the criterion to measure the } \\
\text { characteristics of a geoheritage sites. } \\
\text { - Furthermore, the inventory process for geosites proposed by } \\
\text { Brilha }(2016,2018) \text { uses two different scales for assessing } \\
\text { geoheritage sites with scientific value and educational and } \\
\text { tourism potential. This study argues that scientific value and } \\
\text { educational and tourism potential should be assessed using the } \\
\text { same scale to understand the diversity of the geoheritage site. }\end{array}$ & $\begin{array}{l}\text { - This study included cultural value as part of the inventory process. } \\
\text { This allowed the recognitions of cultural history of the area and how } \\
\text { local communities relate to the geoheritage sites. } \\
\text { - In addition, all the categories were measured on the same scale. } \\
\text { This allowed for the assessment of the diversity of the geological site } \\
\text { and to improve its marketability as the site will offer different } \\
\text { attributes, which might attract tourists from different backgrounds. }\end{array}$ \\
\hline $\begin{array}{l}\text { Fuertes-Gutiérrez } \\
\text { and Fernández- } \\
\text { Martínez (2010) and } \\
\text { Fuertes-Gutiérrez } \\
\text { and Fernández- } \\
\text { Martínez (2012) }\end{array}$ & $\begin{array}{l}\text { - Does not include cultural value as one of the criterion to } \\
\text { measure the characteristics of a geoheritage sites. } \\
\text { - Lack of acknowledgement of previous literature about the } \\
\text { geoheritage site. }\end{array}$ & $\begin{array}{l}\text { - This study included cultural value as part of the inventory process. } \\
\text { This allowed the recognitions of cultural history of the area and how } \\
\text { local communities relate to the geoheritage sites. } \\
\text { - This study included a category on available literature in order to } \\
\text { understand and identify published literature, oral history recordings } \\
\text { and/or any information disseminated about the geoheritage site. }\end{array}$ \\
\hline $\begin{array}{l}\text { Ginting and } \\
\text { Febriand (2018) }\end{array}$ & $\begin{array}{l}\text { - Does not include cultural value as one of the criteria to } \\
\text { assess the characteristics of a geoheritage sites. } \\
\text { - Lack of acknowledgement of previous literature about the } \\
\text { geoheritage site. } \\
\text { - Does not include ecological sensitivity of the geoheritage site. }\end{array}$ & $\begin{array}{l}\text { - This study included cultural value as part of the inventory process. } \\
\text { This allowed the recognitions of cultural history of the area and how } \\
\text { local communities relate to the geoheritage sites. } \\
\text { - This study included a category on available literature in order to } \\
\text { understand and identify published literature, oral history recordings } \\
\text { and/or any information disseminated about the geoheritage site. } \\
\text { - This study introduces the measurement of ecological sensitivity to } \\
\text { measure the capacity of the geoheritage site to withstand visitation } \\
\text { without damaging the ecological sensitivity or value of the site. }\end{array}$ \\
\hline Gordon (2018) & $\begin{array}{l}\text { - The criteria used to } \\
\text { that can be used for ge }\end{array}$ & $\begin{array}{l}\text { - This study explains in detail the crit } \\
\text { of geoheritage sites that can be utili }\end{array}$ \\
\hline Lima et al. (2010) & $\begin{array}{l}\text { - The use of weights to determine the final assessment score is } \\
\text { subjective as the criteria lacks explanation of how the } \\
\text { corresponding weights were determined. In addition, some } \\
\text { criteria's did not have corresponding weights. }\end{array}$ & $\begin{array}{l}\text { - This study explains in detail the criteria used for inventory and } \\
\text { assessment of geoheritage sites that can be utilised for geotourism } \\
\text { development. Furthermore, no corresponding weights were used in } \\
\text { order to avoid subjectivity. }\end{array}$ \\
\hline Page (2004) & $\begin{array}{l}\text { - Does not include cultural value as one of the criterion to } \\
\text { measure the characteristics of a geoheritage sites. } \\
\text { - Absence of category to assess developments required to } \\
\text { make the site suitable for geotourism. } \\
\text { - Lack of acknowledgement of previous literature about the } \\
\text { geoheritage site. }\end{array}$ & $\begin{array}{l}\text { - This study included cultural value as part of the inventory process. } \\
\text { This allowed the recognitions of cultural history of the area and how } \\
\text { local communities relate to the geoheritage sites. } \\
\text { - This study introduces a category to measure developments required } \\
\text { in order to assess what infrastructures exist and in what condition. } \\
\text { - This study included a category on available literature in order to } \\
\text { understand and identify published literature, oral history recordings } \\
\text { and/or any information disseminated about the geoheritage site. }\end{array}$ \\
\hline $\begin{array}{l}\text { Randri } \\
\text { et al. }(2\end{array}$ & $\begin{array}{l}\text { - Suggest that geosites of scientific importance can be valued } \\
\text { as educational sites and those with tourism value can be used to } \\
\text { promote geotourism. } \\
\text { - Absence of category to assess the developments required to } \\
\text { make the site suitable for geotourism. } \\
\text { - Lack of acknowledgement of previous literature about the } \\
\text { geoheritage site. } \\
\text { - The inventory method does not explain how to identify } \\
\text { quantitatively the priority sites. }\end{array}$ & $\begin{array}{l}\text { - This study argues that both scientific importance and tourism value } \\
\text { should be categorised as one because tourists may be interested in both the } \\
\text { scientific and tourism values of the sites. Therefore in this study a site with } \\
\text { geotourism value can be used for both educational and tourism purposes. } \\
\text { - This study introduces a category to measure developments required } \\
\text { in order to assess what infrastructures exist and in what condition. } \\
\text { - This study included a category on available literature in order to } \\
\text { understand and identify published literature, oral history recordings } \\
\text { and/or any information disseminated about the geoheritage site. } \\
\text { - This study details how to quantitatively assess the geoheritage sites and } \\
\text { identify the priority sites that can be used for geotourism development. }\end{array}$ \\
\hline $\begin{array}{l}\text { Reynald } \\
\text { et al. (2007) }\end{array}$ & $\begin{array}{l}\text { - Absence of category to ass } \\
\text { make the site suitable for geot }\end{array}$ & $\begin{array}{l}\text { - This study introduces a category to measure develo } \\
\text { in order to assess what infrastructures exist and in wha }\end{array}$ \\
\hline $\begin{array}{l}\text { South African } \\
\text { National Parks } \\
(2018)\end{array}$ & $\begin{array}{l}\text { - Lack of criteria to assess and prioritise geoheritage sites. } \\
\text { South African National Parks (2018) was only used to locate } \\
\text { the geoheritage sites within the ecological sensitivity map of } \\
\text { the Kruger National Park. }\end{array}$ & $\begin{array}{l}\text { - This study introduces new criteria to assess and prioritise } \\
\text { geoheritage sites. }\end{array}$ \\
\hline $\begin{array}{l}\text { United Nations } \\
\text { Economic } \\
\text { Commission for } \\
\text { Africa (2015) } \\
\end{array}$ & $\begin{array}{l}\text { - Lack of criteria to assess and prioritise geoheritage sites. United } \\
\text { Nations Economic Commission for Africa (2015) was only } \\
\text { used in this study to understand the importance of management } \\
\text { and protection of natural resources such as geoheritage sites. }\end{array}$ & $\begin{array}{l}\text { - This study introduces new criteria to assess and prioritise } \\
\text { geoheritage sites. }\end{array}$ \\
\hline $\begin{array}{l}\text { Wimbledon et al. } \\
(2000)\end{array}$ & $\begin{array}{l}\text { - Absence of category to assess developments required to } \\
\text { make the site suitable for geotourism. } \\
\text { - The inventory method does not explain how to identify } \\
\text { quantitatively the priority sites. }\end{array}$ & $\begin{array}{l}\text { - This study introduces a category to measure developments required } \\
\text { in order to assess what infrastructures exist and in what condition. } \\
\text { - This study details how to quantitatively assess the geoheritage sites and } \\
\text { identify the priority sites that can be used for geotourism development. }\end{array}$ \\
\hline
\end{tabular}


Figure 2 represents the final survey form with six categories of assessment to take to the field. However, before this field trial, the instrument was discussed with the statistical services consultancy at the University of Johannesburg and SANParks head office experienced staff to find a manner to determine scoring the categories for measuring geotourism potential at the KNP. This resulted in a decision not to use weightings per category to avoid assessor subjectivity but rather use a Likert scale. All categories were finally assessed on a one to five Likert scale (Figure 2) of very low, low, moderate, high, and, very high.

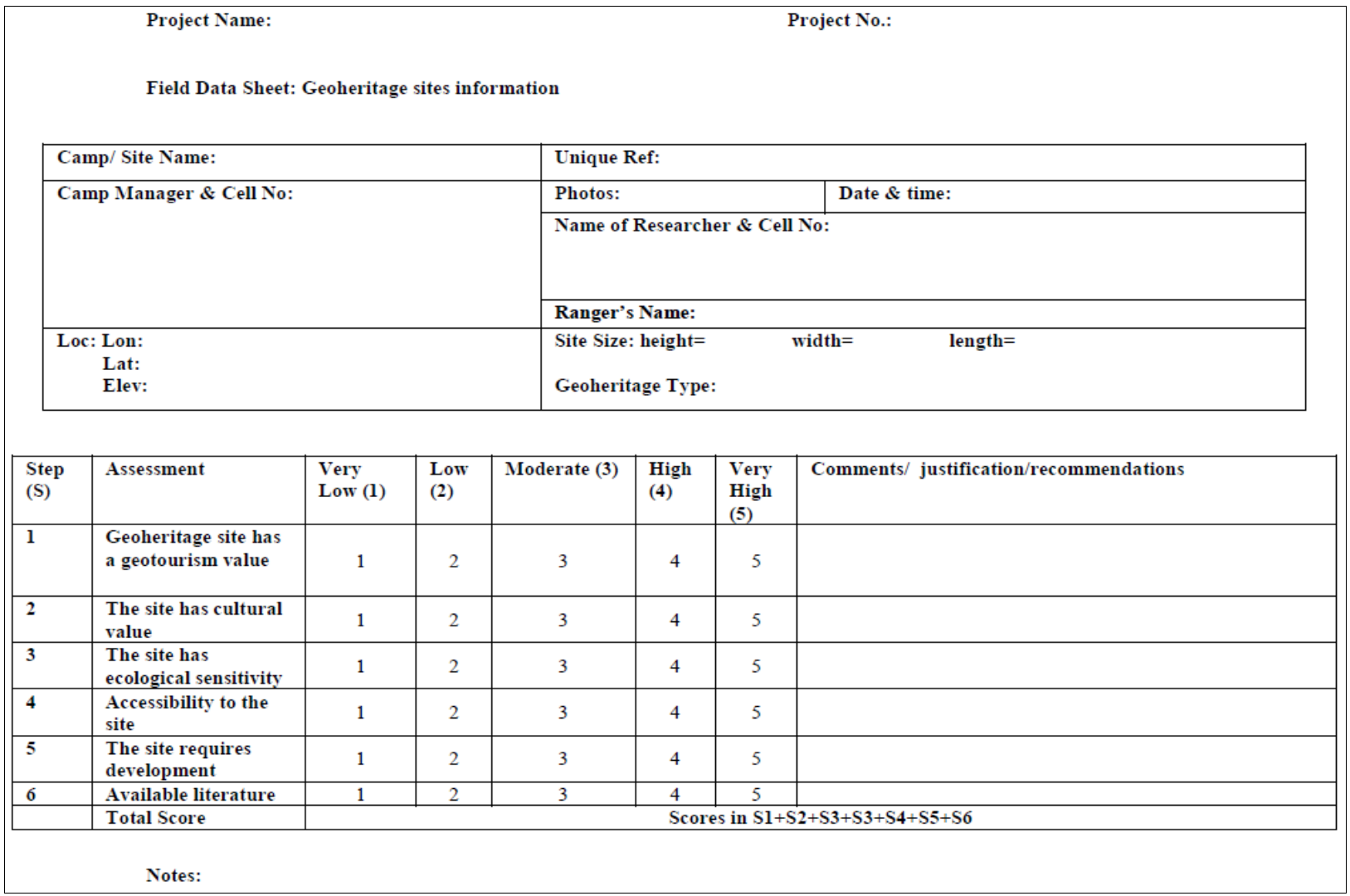

Figure 2. Geoheritage sites field ranking sheet (Authors, 2020)

The use of Likert scale (Likert, 1932) helps in determining the geoheritage sites with a high priority for geotourism development by adding their final score. Likert scale was also selected because it is easy to understand for effective collection of geoheritage sites data in field by novice researchers such as park's staff. SANParks also requested the addition of an ecological sensitivity as a criterion to be collected. Lima et al. (2010) notes that to create a useful geoheritage site inventory in terms of developing geotourism opportunities, a geoconservation strategy should be adopted to evaluate each site. Lima et al. (2010) recommended three considerations as follows: geoheritage site characterisation quantified by their possible relevance to a tourist; the requirement for protection from vandalism and desecration or simply general tourist wear and tear from visits, which is applied according to South African national legal frameworks for geoheritage site conservation; and finally estimating a site value. These recommendations were applied to quantitatively rank each of three sites explored to evaluate the instrument. Table 2 links the sites explored to the UNESCO recommendations.

\section{RESULTS AND IMPLICATIONS}

\section{PHASE TWO: Field ranking and scoring using the field instrument}

The six categories of the survey (Figure 1) are now explained as to their contribution to identifying geoheritage sites with potential for geotourism development:

1. Geotourism value: According to Tongkul (2006), scientific value refers to the important geological records or history of the earth (e.g. fossils, rock types and unconformity). This category includes palaeontological features such as dinosaurs and/or fossils. Age (first or oldest) of features is a factor, however cannot automatically be equated with the best and this does not rule out new unexploited features (Wimbledon et al., 2000). This study groups earth sciences/geology and palaeontology together because of the following reasons:

- Palaeontology is a branch of geology/geosciences (Tongkul, 2006; Sallam et al., 2018). To support this, at the University of Witwatersrand (the only institution offering Bachelor of Science with honors in palaeontology in South Africa) students need to have studied geology. Furthermore, palaeontology is within the geology/geosciences/earth sciences schools or departments at universities such as University of Witwatersrand.

- Dinosaurs and fossils are fundamental to the geological time scale in that in order to determine the age of most layered rocks scientists study the fossils these rocks contain (Edwards and Projeta, 2003).

- Most fossils are seen engraved in rocks as palaeontologist have major challenges extracting fossils from their host rocks (Cunningham et al., 2014).

- A stratigraphic site, a single exposure, can be at the same time palaeontological, sedimentary, geochronological, palaeoenvironmental, petrographic, and historic-geoeconomic, and be the place to identify a time-stratigraphic unit (Wimbledon et al., 2000).

Ranking and scoring was done as follows: geoheritage site that has one or more geological features common throughout South Africa was scored very low as regards interest for a tourist; a geoheritage site that has one or more types of geological features that is less common in across South Africa was scored low; a geoheritage site that has one or more types of geological features unique to the 
Limpopo Province incorporating the KNP not common in other provinces was scored moderate, a geoheritage site that has one or more types of geological features with unique features for the KNP and South Africa was scored high; while a geoheritage site that has one or more types of geological features which are unique and uncommon in South Africa and, neighbouring countries was score very high (Figure 1). This categorisation is based on previous published studies.

2. Cultural value: For the purpose of this research, cultural value is considered as the presence of monuments and groups of buildings, which are outstanding from a historical, art or science point of view in accordance with the United Nations Educational, Scientific and Cultural Organization (1972b) resolutions. The cultural value category also considers local indigenous knowledge of the site associated with traditional use, local beliefs, and historic and archaeological records (Tongkul, 2006). This study category assisted in determining if the site is worth conserving as a representative example of the community's heritage. This category helps to determine the marketability of the area. For both the dedicated geotourist and the general visitor who has less specialised interest in geology, the nature-culture symbiosis provides a means to enhance the visitor experience of engaging with geoheritage through different aspects of landscape appreciation (Gordon, 2018). Ranking and scoring was done as follows: geoheritage site that has one or more monuments and/or groups of buildings, cemeteries/graves, paintings, iron smelters which is located $>10 \mathrm{~km}$ away from a road was scored very low; geoheritage site that has one or more monuments and/or groups of buildings, cemeteries/graves, paintings, iron smelters located 5-10 km away was scored low; geoheritage site that has one or more monuments and/or groups of buildings, cemeteries/graves, paintings, iron smelters which is located 1-5 km away was scored moderate; geoheritage site that has one or more monuments and/or groups of buildings, cemeteries/graves, paintings, iron smelters which is located $500 \mathrm{~m} \mathrm{-1} \mathrm{km} \mathrm{away} \mathrm{was} \mathrm{scored} \mathrm{high;} \mathrm{geoheritage} \mathrm{site} \mathrm{that} \mathrm{has} \mathrm{one} \mathrm{or} \mathrm{more}$ monuments and/or groups of buildings, cemeteries/graves, paintings, iron smelters which is located $<500 \mathrm{~m}$ away was scored very high.

3. Ecological sensitivity: This category is used to determine the potential impacts on the ecological sensitivity of the park using the SANParks sensitivity map (South African National Parks, 2008, 2018). Ranking and scoring was done as follows: geoheritage site located within wilderness zone (WZ) was scored very low; geoheritage site located within remote zone (RZ) was score low; geoheritage site located within the primitive zone (PZ) will be scored moderate; geoheritage site located within low intensity leisure zone (LILZ) was scored high; while geoheritage site located within high intensity leisure zone (HILZ) was scored very high.

4. Accessibility: This category is designed to collect information about accessibility of the site in terms of proximity to road infrastructure. Ranking and scoring was done as follows: a geoheritage site that is located in a remote area ( $>5 \mathrm{~km}$ from the main road) with no sign of human access was scored very low; geoheritage site that is located in a remote area ( $>5 \mathrm{~km}$ from major road) with evidence of human access was scored low; geoheritage site located in a less remote area (1-5 km from major road) with evidence of human access was scored moderate; geoheritage site located $<1 \mathrm{~km}$ from major road with evidence of human access was scored high; geoheritage site located $<1 \mathrm{~km}$ from major road with clear evidence of human access (people seen on site, footprints, vehicle tracks etc.) was scored very high (Figure 1). In order to understand the accessibility of a geoheritage site, the following questions pose as examples of what was also be considered by the researcher during the course of the study: does the site represent potential hazards for visitors? Is the effort required by tourists to get to it too difficult to make a visit worthwhile (time, cost, effort)? Is the site accessible for disabled people?

5. Development required: This involves an investigation of how much development would be needed to get the site tourist friendly and determine the types of developments that are needed. These categories really require a judgement as to what infrastructures exist and in what condition. Ranking and scoring was done as follows: geoheritage site that is unsuitable for geotourism of any form unless major developments are done and has no infrastructure (e.g. power lines, ablutions, buildings, fences and/or water etc.) was scored very low; geoheritage site with non-functioning infrastructure (e.g. power lines, ablutions, buildings, fences and/or water etc.) was scored low; geoheritage site with infrastructure (e.g. power lines, ablutions, buildings, fences and/or water etc.) but requires additional developments was scored moderate; geoheritage site with functioning infrastructure (e.g. power lines, ablutions, buildings, fences and/or water etc.) that requires minor maintenance was scored high; geoheritage site with functioning infrastructure (e.g. power lines, ablutions, buildings, fences and/or water etc.) that requires no repairs will be scored very high.

6. Literature available: This category was used to identify previous studies related to that particular type of geoheritage site. This refers to published literature, oral history recordings and/or any information about the geoheritage site. This step was conducted before and after the fieldwork to complete the survey form. Ranking and scoring was done as follows: a site with no publication was scored very low; a site with one publication was scored low; a site with two publications was scored moderate; a site with three publications was scored high; a site with four, or more publications was scored very high. A higher aggregate score indicates high potential or tourism importance for geotourism development, while a lower score indicates low potential or importance. Geoheritage sites with the higher scores will be recommended to be prioritised for geotourism development by SANParks.

\section{PHASE THREE: TRIAL GEOHERITAGE SITE DATABASE PREPARATION}

The information collected during the inventory and field ranking, and scoring phases was used to prepare a database on geoheritage sites for the northern KNP. All visited geoheritage sites were included in the trial database inventory with specific information including their location global positioning coordinates and proximity to a park main road. Tools for geoheritage site data collection include a Garmin GPSmap 62s to map location of geotourism sites and a Nikon CoolPix AW130 camera for site pictures. This is to guarante the acquired knowledge is preserved to maximise its usage for geotourism development. This was also done to ensure that identified geoheritage sites are properly maintained and protected. This database promote systematic inventory of geoheritage sites with in and around the KNP.Two sites were reviewed in the KNP Limpopo region as a pilot (Table 2).

Table 2. Trailed KNP geoheritage sites (Authors, 2020)

\begin{tabular}{|c|c|l|}
\hline Site Name & Site Type & \multicolumn{1}{c|}{ Field Observation Notes } \\
\hline Thulamela & Mixed & $\begin{array}{l}\text { Geology, cultural landscape and history (geological formations, portholes, baobab trees and artefacts). The site has } \\
\text { very high geotourism value and cultural value as explained in Figure 1 and phase 2 of the methodological approach. }\end{array}$ \\
\hline Crooks Corner & Cultural & $\begin{array}{l}\text { Historical movement of people. The site has very low geotourism value and cultural value as explained in Figure 1 and } \\
\text { phase 2 of the methodological approach. }\end{array}$ \\
\hline
\end{tabular}

Table 3. Ranking results for the three trailed KNP geoheritage sites (Authors, 2019)

\begin{tabular}{|c|c|c|c|c|c|c|c|}
\hline Name & $\begin{array}{c}\text { Geotourism } \\
\text { Value }\end{array}$ & $\begin{array}{c}\text { Cultural } \\
\text { Value }\end{array}$ & $\begin{array}{l}\text { Ecological } \\
\text { Sensitivity }\end{array}$ & Accessibility & $\begin{array}{c}\text { Development } \\
\text { Requirements }\end{array}$ & $\begin{array}{c}\text { Available } \\
\text { Literature }\end{array}$ & $\begin{array}{c}\text { Total Ranking } \\
\text { Score }\end{array}$ \\
\hline Thulamela Heritage Site & 5 & 5 & 4 & 5 & 1 & 5 & 25 \\
\hline Crooks Corner & 1 & 5 & 4 & 5 & 1 & 5 & 21 \\
\hline
\end{tabular}


Table 2 was created based on the results of field ranking of the two sites (Table 3 ). All two sites had never been classified by geoheritage criteria before. The geoheritage sites were evaluated and prioritised based on six categories: their geotourism value, cultural value, ecological sensitivity, accessibility, development requirements and available literature about the site. The ranking results of the two piloted sites (Table 3) shows that Thulamela heritage site has potential for geotourism development than Crooks Corner.

\section{CONCLUSIONS}

The results of this study are vital in developing geotourism at the northern part of the KNP. A literature review about the inventory process used in several countries allowed the development of a new methodology proposed in this paper. Because of this study, the geotourism potential at the KNP is now better recognised. This study has identified a systematic site exploration methodology that can be used towards geotourism development at the KNP. The developed method of determining potential geotourism serves as a guideline for future studies in South African national park and national parks beyond the African continent and globally.

This study is important since it highlights that to identify geotourism potential and implications for management involves not only tailoring a methodology that is designed for case context, that may best work to provide the relevant data, but also involves the engagement of key stakeholders (e.g. those working in parks) for research design and for methodology effectiveness. Since many countries make no formal acknowledgment that geosites are cultural and scientific places of national importance, a contextual methodology design can ensure that unique characteristics for geosites are recognised and marketed accordingly. The case meth odology designed and employed at the KNP shows that geotourism can offer a new secondary product to supplement the existing tourism market and to utilise natural capitals with unique characteristics for the benefits of local people.

In South Africa and many other countries, geoheritage sites at national parks are at risk of degradation or being damaged. This is because the national entities are not even aware of this threat because there is no systematic inventory of geoheritage sites. Best practice to coordinate geotourism advancement to all park stakeholders in any country would be to offer positive communication highlighting the outcomes tailored for each stakeholder type and for a nation as a whole. A legitimate authority in each country, in this case the South African national parks, needs to champion the less understood value of being a geotourist as opposed to the traditional wildlife or wild biome tourist. This latter type of tourist has been widely reported in the past decades in academic literature as to the manner of exploring their perceptions and expectations from tourism offerings but the same cannot be said of geotourist interests and specifically the role of park-abutting, local communities who want to benefit from goetourist activities. A wide range of recommendations on the value of creating and main taining national parks/ protected areas exists but globally a more consolidated effort needs to be led by each country and their rese archers to support international conventions and standards appraised at national, state and local levels for geotourism activities.

This would lead to the geotourist gaining a valid perception of the geotourism offering before embarking on their trip much as international hospitality indices rate countries today for global traveller and destination manager use. A primary goal for park management is to ensure tourists are provided with a level of service that ensures a high level of satisfaction from experiences with park's products and inventory of the geosite in the manner described, helps ensure this is attained. Academic research has already acknowledged a strong causal effect between behavioural intentions of satisfied tourists to market positively a tourism offer ing by wordof-mouth. The methodology applied in this research advances the existing methods for geotourism inventory using a South African park that deals with specific complexities such as lack of tarred or even dirt road park road infrastructure to an interesting site, providing tourist amenity infrastructure in a park that is many kilometres wide and long, considerations of how to manage interactions between potential dangerous animals and geotourists and most importantly, using unique local indigenous knowledge to create a way to transfer indigenous knowledge to future generations. This latter consideration of the potential contribution towards preservation of cultural knowledge and local community development in communities abutting a park has not been well explored. As the pressure from the human species increases with the globally burgeoning population, so parks will need to argue more and more strongly for their existence in terms of satisfying tourist type demands balanced with local community needs for sustainable livelihoods arising from the park. In response to challenges such as climate change and global warming, the need to encourage sustainable business practice making inclusive use of indigenous knowledge cannot be ignored and communities abutting national parks with unique insights into geoheritage as an indigenous knowledge source cannot be ignored lest it be forgotten. Geotourism inventory using the described methodology is proposed here to have an extremely important role to play influencing indigenous knowledge preservation.

This study presented was the first of its kind to present a uniquely South African manner of taking inventory of geoheritage sites in South Africa that can assist with opening new tourism opportunities for creation of local employment, park management, and improve academic knowledge on geotourism. The outcomes of this study will assist the South African National Parks and the National Department of Tourism to develop geotourism as a secondary tourism market product in order to supplement the primary (wildlife) tourism market, to preserve local indigenous knowledge of an area and, to develop a more encompassing and balanced interrelationship of people, planet and profit in a national conservation strategy. The lessons learned through this study were that, development of an inventory process for development of geotourism requires willingness and cooperation among different role players including the researchers, lead national departments, management entities, academics, statisticians and local communities. This study was conducted with the strategic intent towards influencing decisions to develop geotourism in South Africa and beyond as a new market segment to alleviate poverty especially in rural areas. The next phase of this study will include the prioritisation of geoheritage sites using the proposed method as explained in this paper and the creation of hot spots maps to identify the geoheritage sites with high geotourism potential.

\section{REFERENCES}

Anhaeusser, C.R., Viljoen, M.J., \& Viljoen, R.P. (2016). Africa's Top Geological Sites. Cape Town, South Africa, Struik Nature.

Arora, K., Rajput, S., \& Anand, R.R. (2020). Geomorphosites Assessment for the Development of Scientific Geo-tourism in North and Middle Andaman's, India. Geojournal of Tourism and Geosites, 32(4), 1244-1251. https://doi.org/10.30892/gtg.32408-564

Badang, D.A., \& Unjah, T. (2013). Communicating Geoheritage: Linking Culture and Geology in Delta Sarawak Geopark. Paper presented at the $3^{\text {rd }}$ Asia Pacific Geoparks Network Symposium. Jeju Island, South Korea.

Boley, B.B., Nickerson, N.P., \& Bosak, K. (2011). Measuring Geotourism: Developing and Testing the Geotraveler Tendency Scale (GTS). Journal of Travel Research, 50, 567-578. https://doi.org/10.1177\%2F0047287510382295

Brilha, J. (2016). Inventory and Quantitative Assessment of Geosites and Geodiversity Sites: A Review. Geoheritage, 8, 119-134. https://doi.org/10.1007/s12371-014-0139-3

Brilha, J. (2018). Geoheritage: Inventories and Evaluation. Chapter 4, In E. Reynald, and J. Brilha (Eds.), Geoheritage Assessment, Protection and Management. https://doi.org/10.1016/B978-0-12-809531-7.00004-6

Cairncross, B. (2011). The National Heritage Resource Act (1999): Can Legislation Protect South Africa's Rare Geoheritage Resources? Resources Policy, 36(3), 204-213. https://doi.org/10.1016/j.resourpol.2011.04.002 
Carcavilla, L., Durán, J.J., García-Cortés, A., \& López-Martínez, J. (2009). Geological Heritage and Geoconservation in Spain: Past, Present, and Future. Geoheritage, 1(75), 1-18. https://doi.org/10.1007/s12371-009-0006-9

Chingombe, W., \& Taru, P. (2018). Rural Geotourism as an Option for Development in Phuthaditjhaba: Golden Gate National Park Area, South Africa. African Journal of Hospitality, Tourism and Leisure, 7(1), 1-11.

Cunningham, J.A., Rahman, I.A., Latenschlager, S., Rayfield, E.J., \& Donoghue, P.C.J. (2014). A Vitual World of Paleontology. Trends in Ecology and Evolution, 29(6), 347-357. http://doi.org/10.1016/j.tree.2014.04.004

Dingwall, P., Weighell, T., \& Badman, T. (2005). Geological World Heritage: A Global Framework. A Contribution to the Global Theme Study of World Heritage Natural Sites. Protected Area Programme. Switzerland, IUCN.

Dowling, R.K., \& Newsome, D. (2010). Global Geotourism Perspectives. Woodeaton, Oxford, England, Goodfellow Publishers Limited.

Edwards, L.E., \& Projeta, J. (1993). Fossils, Rocks and Time. Denver, USA, U.S. Geological Survey.

Ehsan, S., Leman, M.S., \& Begum, R.A. (2013). Geotourism: A Tool for Sustainable Development of Geoheritage. Advanced Materials Research, 622-623, 1711-1715. http://doi.org/10.4028/www.scientific.net/AMR.622-623.1711

Ehsan, S., Begum, R.A., \& Leman, M.S. (2016). Competitive Advantage of Geotourism Market in Malaysia: A Comparsion among ASEAN Economies. Procedia - Social and Behavioral Sciences, 219, 228-234. https://doi.org/10.1016/j.sbspro.2016.05.010

El Wartiti, M.E., Malaki, A., Zahraoui, M., Di Gregorio, F., \& De Waele, J. (2009). Geosites And Touristic Development of the North-western Tabular Middle Atlas of Morocco. In A. Marini and M. Talbi (Eds.) Desertification and Risk Analysis Using High and Medium Resolution Satellite Data, 143-156. http://doi.org/10.1007/978-1-4020-8937-4

Emas, R. (2015). The Concept of Sustainable Development: Definition and Defining Principles. Accessed the 17th of May 2017. https://sustainable development.un.org/content/documents/5839GSDR\%202015_SD_concept_definiton_rev.pdf

Farsani, N.T., Coelho, C., \& Costa, C. (2011). Geotourism and Geoparks as Novel Strategies for Socio-economic Development in Rural Areas. International Journal of Tourism Research, 13, 68-81.

Fuertes-Gutiérrez, I., \& Fernández-Martínez, E. (2010). Geosites Inventory in the Leon Province (Northwestern Spain): A Tool to Introduce Geoheritage into Regional Environmental Management. Geoheritage, 2, 57-75. https://doi.org/10.1007/s12371-010-0012-y

Fuertes-Gutiérrez, I., \& Fernández-Martínez, E. (2012). Mapping Geosites for Geoheritage Management: A Methodological Proposal for the Regional Park of Picos de Europa (Leo'n, Spain). Environmental Management, 37, 1-25. https://doi.org/10.1007/s00267-012-9915-5

Gibson, R.L., \& Blom, M. (2008). Geotourism Potential of the Vredefort Dome, South Africa - Challenges, Opportunities, Progress and Recommendations Large Meteorite Impacts and Planetary Evolution, IV, 3112. https://www.lpi.usra.edu/meetings/lmi2008/pdf/3112.pdf. Accessed the 25th of August 2017.

Ginting, N., \& Febriand, Y. (2018). Implementation of Geotourism Concept in Developing Natural Tourist Attraction at Parbaba Village, Toba's Caldera. IOP Conference Series: Earth and Environmental Science, 126, 1-9. https://doi.org/10.1088/1755-1315/126/1/012160

Goodland, R. (1995). The Concept of Environmental Sustainability. Annual Review of Ecology and Systematics, 26, 1-24. http://links.jstor.org/sici?sici=0066$4162 \% 281995 \% 2926 \% 3 \mathrm{C} 1 \% 3 \mathrm{ATCOES} \% 3 \mathrm{E} 2.0 . \mathrm{CO} \% 3 \mathrm{~B} 2-\mathrm{F}$

Gordon, J.E. (2018). Geoheritage, Geotourism and the Cultural Landscape: Enhancing the Visitor Experience and Promoting Geoconservation. Geosciences, 8(4), 2-25. http://doi.org/10.3390/geosciences8040136

Grünewald, C. Schleuning, M., \& Böhning-Gaese, K. (2016). Biodiversity, Scenery and Infrastructure: Factors Driving Wildlife Tourism in an African Savannah National Park. Biological Conservation, 201, 60-68. http://doi.org/10.1016/j.biocon.2016.05.036

Harris, J.M. (2000). Basic Principles of Sustainable Development. Global Development and Environment Institute, Working Paper 00-04. Accessed the 25th of August 2017. http://ase.tufts.edu/gdae/publications/working_papers/Sustainable\%20Development.pdf

Härtling, J.W., \& Meier, I. (2010). Economic Effects of Geotourism in Geopark TERRA.Vita, Northern Germany. Geoparks, $27,29-39$.

Hose, T.A. (2012). Editorial: Geotourism and Geoconservation. Geoheritage, 4(1-2), 1-5. https://doi.org/10.1007/s12371-012-0059-z

Hose, T.A. (2016). Geoheritage and Geotourism: A European Perspective (Heritage Matters). Woodbridge, England, Boydell Press.

Iftode, S.G., \& Niculae, L. (2016). Geoeducation and Geotourism - Important Tools for Geoconservation: The Case of Buzau Land Aspiring Geopark, Romania. Paper presented at the $8^{\text {th }}$ Conference of the Association of African Women in Geosciences (CAAWG). Sibiu, Romania: $1-7$ June 2016.

Jeon, Y., Koh, J.G., \& Lee, S. (2016). Case Study on the Geotrail Revitalization in the Jeju Island Geopark, Republic of Korea. Paper presented at the $7^{\text {th }}$ International Conference on UNESCO Global Geoparks. English Riviera UNESCO Global Geopark, United Kingdom: 27-30 September 2016.

Justice, S.C. (2018). UNESCO Global Geoparks, Geotourism and Communication of the Earth Sciences: A Case Study in the Chablais UNESCO Global Geopark, France. Geosciences, 8(149), 1-11. https://doi.org/10.3390/geosciences8050149

Knight, J., Grab, S., \& Esterhuysen, A.B. (2015). Geoheritage and Geotourism in South Africa. In S. Grab, and J. Knight (Eds.) Landscapes and Landforms of South Africa, World Geomophological Landscapes. Charm, Switzerland, Springer. https://doi.org/10.1007/978-3-319-03560-4_19

Likert, R. (1932). A Technique for the Measurement of Attitudes. Archives of Psychology, 22 (140), 5-55.

Lima, F.F., Brilha, J.B., \& Salamuni, E. (2010). Inventorying Geological Heritage in Large Territories: A Methodological Proposal Applied to Brazil Geoheritage, 2(3-4), 91-99. https://doi.org/10.1007/s12371-010-0014-9

Matiza, T., \& Oni, O.A. (2014). The Perceived Economic Benefits of Tourism: The Case of a Rural Community Bordering the Kruger National Park in Limpopo Province, South Africa. Mediterranean Journal of Social Sciences, 5(20), 322-328. http://doi.org/10.5901/mjss.2014.v5n20p322

Mitcham, C. (1995). The Concept of Sustainable Development: Its Origins and Ambivalence. Technology in Society, 17(3), 311-326. https://doi.org/ 10.1016/0160-791X(95)00008-F

Mukwada, G., \& Sekhele, N. (2017). The Potential of Community-based Geotourism in Rural Development in South Africa: The Case of Witsie Cave Project. Journal of Asian and African Studies, 52(4), 471-483. https://doi.org/10.1177/0021909615595991

Munasinghe, M. (1993). Environmental Economics and Sustainable Development. Accessed the 25th of July 2017. http://documents.worldbank.org/curated/ en/638101468740429035/pdf/multi-page.pdf

Newsome, D., \& Dowling, R. (2010). Setting an Agenda for Geotourism. In D. Newsome, \& R.K. Dowling (Eds.) Geotourism - The Tourism of Geology and Landscape. Oxford, England, Goodfellow Publishers Limited.

Newsome, D., Dowling, R., \& Leung, Y. (2012). The Nature and Management of Geotourism: A Case Study of Two Established Iconic Geotourism Destinations. Tourism Management Perspective, 2, 19-27. Amsterdam, Netherlands, Elsevier. https://doi.org/10.1016/j.tmp.2011.12.009

Newsome, D., \& Dowling, R. (2018). Geoheritage and Geotourism. In E. Reynard \& J. Brilha (Eds.) Geoheritage - Assessment, Protection and Management. Amsterdam, Netherlands, Elsevier. https://doi.org/10.1016/B978-0-12-809531-7.00017-4

Nooten, G.A. (2007). Sustainable Development and Nonrenewable Resources - A Multilateral Perspective. In Proceedings, Workshop on Deposit Modeling, Mineral Resource Assessment and Sustainable Development, Accessed the 25th of July 2017. https://pubs.usgs.gov/circ/2007/1294/reports/paper6.pdf

Page, K.N. (2004). The Protection of Jurassic Sites and Fossils: Challenges for Global Jurassic Science. Rivista Italiana di Paleontolosia e Stratisrafia, 110 , 373-379. https://doi.org/10.13130/2039-4942/6313

Paungya, N., Singtuen, V., \& Won-In, K. (2020). The Preliminary Geotourism Study in Phetcahbun Province, Thailand. GeoJournal of Tourism and Geosites, 31(3), 1057-1067. https://doi.org/10.30892/gtg.31318-541

Phau, I., Lee, S., \& Quintal, V. (2013). An Investigation of Push and Pull Motivations of Visitors to Private Parks: The Case of Araluen Botanic Park. Journal of Vacation Marketing, 19(3), 269-284. https://doi.org/10.1177/1356766712471232

Randrianaly, H.N., Di Cencio, A., Rajaonarivo, A., \& Raharimahefa, T. (2016). A Proposed Geoheritage Inventory System: Case Study of Isalo National Park, Madagascar. Journal of Geoscience and Environment Protection, 4(5), 163-172. http://doi.org/10.4236/gep.2016.45016

Reimold, W.U. (1999). Geoconservation - A Southern African and African Perspective. Journal of African Earth Science, 29(3), 469-483. https://doi.org/ $10.1016 / \mathrm{S} 0899-5362(99) 00110-4$ 
Reimold, W.U. (2001). Tourism, Ecotourism, Geotourism! A Case for a New National Tourism Strategy. Geobulletin, 44(4), 20-23.

Ren, F., Simonson, L., \& Pan, Z., (2013). Interpretation of Geoheritage for Geotourism - A Comparison of Chinese Geoparks and National Parks in the United States. Czech Journal of Tourism, 2(2), 105-125. http://doi.org/10.2478/cjot-2013-0006

Reynald, E., Fontana, G., Kozlik, L., \& Scapozza, C. (2007). A Method for Assessing Scientific and Additional Values of Geomorphosites. Geographica Helvetica, 62(3), 148-158.

Rozenkiewicz, A., Widawski, K., \& Jary, Z. (2020). Geotourism and the 21st Century-NTOs' Website Information Availability on Geotourism Resources in Selected Central European Countries: International Perspectives. Resources, 9(4), 2-28. http://doi.org/10.3390/resources9010004

Ruban, D.A. (2015). Geotourism - A Geographical Review of the Literature. Tourism Management Perspectives, 15, 1-15. http://doi.org/10.1016/j.tmp.2015.03.005

Saayman, M. (2017). Nature Based Tourism and a Framework for Socio-economic Research. Paper presented at the Science and Sustainable Tourism, NSTF Discussion Forum. Kempton Park, South Africa: 3 August 2017.

Sallam, E.S., Ponedelnik, A.A., Ties, G., Yashalova, N.N., \& Ruban, D.A. (2018). The Geological Heritage of the KurkureDungul Area in Southern Egypt. Journal of African Earth Sciences, 137, 103-115. https://doi.org/10.1016/j.jafrearsci.2017.10.012

Santangelo, N., \& Valente, E. (2020). Geoheritage and Geotourism Resources. Resources 9(80), 1-5. http://doi.org/10.3390/resources9070080

Scholtz, M., Kruger, M., \& Saayman, M. (2013). Understanding the Reasons Why Tourists Visit the Kruger National Park During a Recession. Acta Commercii, 13(1), 1-9. http://doi.org/10.4102/ac.v13i1.168

Schutte, I. (2003). Documenting Geosites in the Kruger National Park: Part I. Geobulletin, 46(4), 19-21.

Schutte, I.C. (2009). A Strategic Management Plan for the Sustainable Development of Geotourism in South Africa. Doctoral Thesis, University of North West, Potchefstroom, South Africa.

Smit, J.J. (2003). Geotourism in South Africa: Problems and Prospects. Masters Dissertation, University of Johannesburg, Johannesburg, South Africa.

Strickland-Munro, J., Moore, S., \& Freitag-Ronaldson, S. (2010). The Impacts of Tourism on Two Communities Adjacent to the Kruger National Park, South Africa. Development Southern Africa, 27(5), 663-678. h,ttp://doi.org/10.1080/0376835X.2010.522829

Strickland-Munro, J., \& Moore, S. (2014). Exploring the Impacts of Protected Area Tourism on Local Communities Using a Resilience Approach. Koedoe, 56(2), 1-10. http://doi.org/10.4102/koedoe.v56i2.1161

Taru, P., \& Chingombe, W. (2016). Geoheritage and the Potential of Geotourism in the Golden Gate Highlands National Park, South Africa. African Journal of Hospitality, Tourism and Leisure, 5(2), 1-11.

Tongkul, F. (2006). Geotourism in Malaysian Borneo. In D. Newsome, \& R. Dowling (Eds.), Geotourism - Sustainability, Impacts and Management. Oxford, England, Elsevier Ltd.

Stokes, A.M., Cook, S.D., \& Drew, D. (2003). Geotourism: The New Trend in Travel. Accessed the 18th of September 2017. http://www.egret.us/clinton/ Geotourism\%20The\%20New\%20Trend\%20in\%20Travel.pdf

Viljoen, M.J., \& Reimold, W.U. (1999). An Introduction to South Africa's Geological and Mining Heritage. South Africa, Geological Society of South Africa and Mintek.

Widawski, K., Olesniewicz, P., Rozenkiewicz, A., Zareba, A., \& Jandova, S. (2020). Protected Areas: Geotourist Attractiveness for Weekend Tourists based on the Example of Gorczański National Park in Poland. Resources 9(35), 1-28. http://doi.org/10.3390/resources9040035

Wimbledon, W.A.P., Ishchenko, A.A., Gerasimenko, N.P., Karis, L.O., Suominen, V., Johansson, C.E., \& Freden, C. (2000). Geosites - An IUGS Initiative: Science Supported by Conservation. In D. Barettino, W.A.P. Wimbledon \& E. Gallego (Eds.) Geological Heritage - Its Conservation and Management. Spain, IGME

Wimbledon, W.A.P., \& Smith-Meyer, S. (2013). Geoheritage in Europe and its Conservation. Oslo, Norway, ProGEO.

Zouros, N. (2016). The Global Geoparks Network: The International Association of UNESCO Global Geoparks. Paper presented at the $7^{\text {th }}$ International Conference on UNESCO Global Geoparks. English Riviera UNESCO Global Geopark, United Kingdom: 27-30 September 2016.

**** International Congress of Geotourism (2011). Arouca Declaration on Geotourism. Accessed the 3rd of February 2018. http://www.europeangeoparks.org/?p=223

*** South African National Parks (2008). Kruger National Park Management Plan. Accessed the 7th of February 2017. https://www.sanparks.org/ assets/docs/conservation/park_man/knp-management-plan1.pdf

*** South African National Parks (2012). Report on Corporate Social Investment Programmes. Accessed the 7th of February 2017. https://www.sanparks.org/assets/docs/about/reports/social-investment-report-2012.pdf

**** South African National Parks (2017). Annual Report 2016/17. Accessed the 18th of June 2018. https://www.sanparks.org/assets/docs/general/annual-report-2017.pdf

*** South African National Parks (2018). Kruger National Park Management Plan. Accessed the 29th of January 2018. https://www.sanparks. org/assets/docs/conservation/park_man/knp/draft-plan.pdf

*** United Nations Economic Commission for Africa. (2015). Africa Regional Report on the Sustainable Development Goals: Summary. Accessed the 18th of August 2017. https://www.uneca.org/sites/default/files/uploaded-documents/SDG/africa_regional_report_on_the_sustainable_development_goals_summary_english_rev.pdf

*** United Nations Educational, Scientific and Cultural Organization (1972a). Convention Concerning the Protection of the World Cultural and Natural Heritage: Adopted by the General Conference at its Seventeenth Session Paris, 16 November 1972. http://whc.unesco.org/archive/convention-en.pdf Accessed the 8th of February 2017.

*** United Nations Educational, Scientific and Cultural Organization (1972b). Resolutions, Recommendations, Volume 1: Records of the General Conference, Seventeenth Session, 17 October to 21 November 1972, Paris. Accessed the 8th of February 2017. http://unesdoc.unesco.org/images /0011/001140/114044E.pdf

*** United Nations Educational, Scientific and Cultural Organization (2016). "UNESCO Global Geoparks: Celebrating Earth Heritage, Sustaining Local Communities. Accessed the 8th of February 2017. http://unesdoc.unesco.org/images/0024/002436/243650e.pdf

*** United Nations Educational, Scientific and Cultural Organization (2018a). "Global Geoparks". Accessed the 11th of June 2018. http://www.unesco.org/ new/en/natural-sciences/environment/earth-sciences/unesco-global-geoparks/

*** United Nations Educational, Scientific and Cultural Organization (2018b). List of UNESCO Global Geoparks. Accessed the 11 th of June 2018. http://www.unesco.org/new/en/natural-sciences/environment/earth-sciences/unesco-global-geoparks/list-of-unesco-global-geoparks/ 